\title{
Osmanlı Tarih Kitaplarında III. Mehmed'in Cülusunda Öldürülen On Dokuz Şehzade Meselesi
}

\author{
The Question of Nineteen Şehzade Killed During the Enthronement of
}

Mehmed III in the Ottoman History Books

\section{Tuğba DEMİRCi *}

Öz

Osmanlı Devleti'nde veraset sistemi kesin kurallara bağlı olmadığ için her taht değişikliği çok sayıda şehzadenin ölümüne yol açmışır. Fatih'in Teşkilat Kanunnamesi ile kardeş katli hukuksal bir zemine oturtulmuş olsa da şehzadelerin öldürülmesi acı bir olay olarak tarihe geçmiştir. Saltanat kavgasında sadece taht mücadelesine giren kardeşler öldürülmemiş, herhangi bir taht iddiası bulunmayan henüz küçük yaşta olan şehzadeler de katledilmiştir. Şehzadelerin ölümü, Osmanlı devrinde çeşitli tepkilere yol açmıştır. Özellikle Sultan Süleyman'ın oğullarından Mustafa ve Bayezid gibi şehzadelerin katli büyük bir yankı bulmuş, halk arasında derin bir teessüre sebep olmuştur. Keza bazı şehzadelerin katli, geçmişte ve günümüzde tarihçiler ve edebiyatçlar tarafından büyük bir ilgiye mazhar olurken bazılarının katli ise sayısal bir veri olarak kaydedilmiş ve geçiştirilmiştir. Bu bağlamda III. Mehmed'in tahta çıkışıyla birlikte öldürttüğü on dokuz şehzadenin katli de göz ardı edilen ve üzerinde duırulmayan vakıalardandır. Bu makalede on dokuz şehzadenin öldürülmesinin nasıl bir tepkiyle karşılandığı ve Osmanlı tarihlerinde nasıl yer bulduğu ele alınmıştır.

Anahtar Kelimeler: Şehzade, Kardeş Katli, Mersiye, III. Mehmed.

"YLS Öğrencisi, Sakarya Üniversitesi, Sosyal Bilimler Enstitüsü Tarih Anabilim Dalı Yeniçă̆ Tarihi Bilim Dalı

Bu makale iThenticate sistemi tarafından taranmıştır.

Makale Gönderim Tarihi: 9 Ocak 2019 


\begin{abstract}
The succession system in the Ottoman Empire was not bound by strict rules and this fact caused that each new enthronement led to the death of many princes. Although Fatih's code of law constituted a legal basis for fratricide, the princes being killed had been seen as painful events throughout the history. In the struggle for sultanate, not only the brothers in the struggle for the throne, but also the princes who were too young to have any claim to the throne were killed. The practice of fratricide caused various reactions in the Ottoman period. Especially the murder of Mustafa and Bayezid, the sons of Suleyman the Magnificient, found a great reflection in that period of time and caused deep woe among the public. However, while the massacre of some princes attracted the attention of both Ottoman and modern historians, some did not and were just recorded as facts or data. The massacre of nineteen princes following the ascension of Mehmed III was also a neglected event in Ottoman history. In this paper, the reactions to this specific case of fratricide and how it was considered in the contemporary Ottoman sources will be discussed .
\end{abstract}

Keywords: Politics of succession, Fratricide, Mehmed III. 


\section{Giriş}

Osmanlı Devleti denildiğinde toplumsal imgelemde bir taraftan kudretli padişahların yönettiği, adalet ve refah seviyesinin yüksek olduğu, ilim, irfan, kültür ve ahlak bakımından yüksek bir medeniyet ve Türk-İslam devletlerinden devraldığı birikimle ortaya çıkmış bir imparatorluk akla gelmektedir. Diğer taraftan hanedan içinde yaşanan rekabetler, saray komploları ve masum şehzadelerin öldürülmesi adaletsiz ve merhametsiz bir siyasal yapı olarak zihinlerde canlanmaktadır.

Birinci perspektif günümüz toplumunda güçlü ve ihtişamlı bir Osmanlı imgesi ile karşılık bulurken ikincisi Osmanlı düzenine yönelik tepkilere yol açmaktadır. Günümüzde birinci grup şehzadelerin öldürülmesini "nizam-1 alem" ideali ile siyasetin doğası olarak görürken ikinciler başta masum şehzadelerin öldürülmesi olmak üzere saray içi kanlı çekişmeleri, vicdani duyguları örseleyen bir gelişme olarak kabul etmişlerdir. $\mathrm{Bu}$ anlayış ve tutum farklılığı, hiç şüphesiz geçmiş dönemler için de geçerlidir. Mamafih Osmanlı devrinde kardeş katli veya şehzadelerin öldürülmesine yönelik tepkilerin ne olduğu ve Osmanlı duygu dünyasında nasıl bir karşılık bulduğu konusunda yeterli bir inceleme yoktur. Özellikle de III. Mehmed'in tahta çıktığında on dokuz kardeşini katletmiş olması doğrudan bir araştırmaya konu olmadığı gibi bu hadisenin Osmanlı tarihinde nasıl algılandı̆̆ı ve nasıl bir etki yarattığı konusu da gündeme gelmemiştir.

Bu makalede ise III. Mehmed'in cülusunda on dokuz kardeşinin öldürülme hadisesinin Osmanlı tarih kitaplarında nasıl yer bulduğu üzerinde durulacaktır. Bu bağlamda bu elim vakanın, devrinde nasıl bir tepkiye yol açtığı, toplum nezdinde nasıl karşılandığ1 ve Osmanlı tarihinde herhangi bir kırılmaya sebep olup olmadığı değerlendirilecektir. Keza diğer şehzade ölümlerinin tarih kitaplarında nasıl ele alındığı dikkate alınarak karşılaştırmalı bir analiz yapılmaya çalışılacaktır.

\section{a. Osmanlı Tarih Yazımında ve Osmanlı Tarihlerinde Şehzade Katli}

Şehzadelerin katli meselesi, Osmanlı tarih yazımında büyük bir 
ilgiye mazhar olsa da mesele siyasi ve hukuki yönü itibariyle ele alınmış, insani ve vicdani boyutu ile Osmanlı duygu dünyasındaki yansımaları birkaç popüler yazı dışında yeterince ilgi görmemiştir. Şehzadelerin öldürülme hadisesini çoğunlukla bir bilgi olarak aktaran Osmanlı kronik yazarlarının taşıdıkları zihniyet ve alg1, günümüz akademisyenleri ve tarihçilerini etkilemiş ve bu mesele günümüzde de sınırlı bir çerçevede incelenmiştir. Mehmet Akman tarafından kaleme alınan Osmanlı Devletinde Kardeş Katli (Akman, 1997) adlı kitap, konuyla doğrudan alakalı olmakla birlikte kardeş katli meselesi, kronolojik olarak politik ve hukuksal bir çerçevede anlatılmıştır. Ahmet Mumcu, Osmanlı Devletinde Siyaseten Katl (Mumcu, 1963) eserinde siyaseten katl kapsamında tüm hadiseleri ele alırken şehzade katline de ayrı bir bölüm ayırmıştır. Ancak Mumcu da Akman gibi siyasi ve hukuki çerçevenin dışına çıkmamıştır. Abdülkadir Özcan'ın “Fatih'in Teşkilat Kanunnamesi ve Nizam-1 Alem İçin Kardeş Katli Meselesi” (Özcan, 1981) ve Ekrem Buğra Ekinci'nin “Osmanlı Hukukunda Kardeş Katli Meselesi" (Ekinci, 2006) aynı minval üzerinde yazılmış makalelerdir. Muhammet Nuri Tunç'un hanedan içinde yaşanan tüm öldürme hadiselerini araştırdığ 1 "Osmanlı' da Hanedan İçi Katl" (Tunç, 2014) makalesinde de olayın Osmanlı duygu dünyasındaki karşılığına değinilmemiştir.

Hâlbuki şehzadelerden birinin tahta oturduğunda diğer şehzadeleri katletmesi, saray çevresinde ve halk arasında birtakım tepkilere yol açmıştır. Şehzadenin öldürülmesinde, şehzadenin kimliği ve olayın tarihine bağlı olarak farklı tepkiler gösterilmiş olsa da şehzade ölümlerinin dramatik bir vakıa olarak toplumda büyük bir üzüntüye yol açtığı kesindir. Şehzadelerin öldürülmelerine karşı duyulan öfke, kızgınlık, üzüntü ve tevekkül duyguları çeşitli kayıtlarla günümüze kadar gelmiştir. Bunlardan en önemlisi hiç şüphesiz mersiyelerdir. Şairler, şehzadelerin ölümünden etkilenerek mersiyeler yazmış acı, dram ve hüzün içerikli beyitlerin yanı sıra, şehzadelerin haksızlığa uğradıkları yönünde yorumlarda bulunmuşlardır. Cem Sultan'ın oğlu Oğuzhan için yazdığı felek redifli mersiye (Ersoylu, 2013:29-32) Kanuni Sultan Süleyman'ın oğullarından Şehzade Mustafa için kaleme alınan mersiyeler 
(İsen, 1994:283-323), Kanuni'nin diğer oğlu Şehzade Bayezid için Kul Piri tarafından yazılan mersiye (Elçin, 1990:155, 156; Elçin, 1974:78), ile II. Selim'in oğlu Süleyman ve III. Murad'ın şehzadeleri için yazılan mersiyeler (İsen, 1994:324-326), bu babda zikredilebilecek örneklerdendir.

Osmanlı Devleti'nde şehzade ölümleri vicdani anlamda insanların duygu dünyasına tesir etmiş, bu tesir ise tarih kitaplarında bir şekilde yer bulmuştur. Dönemin tarihçileri bazı vakıalarda sessiz kalırken bazılarına ziyadesiyle önem atfetmiş ve yazılarında ön plana çıkartmışlardır. Dolayısıyla şehzadelerin öldürülmeleri ve bunun üzerine ortaya çıkan tepkiler tarihçilerin yazdığı kadarıyla bugüne yansımıştır. Osmanlı tarihlerinde yer alan şehzade ölümleriyle ilgili bilgilere bakıldığında birkaçı haricinde şehzadelerin öldürülme hadiselerinin dikkate alınmadığı ve sıradan bir vaka gibi kaydedildiği görülmektedir. Bu durumun birçok dinamikle bağlantısı olmakla beraber en önemlisi Osmanlı devlet ve siyaset anlayışıdır. Osmanlılardaki devlet ve siyaset anlayışı temelde nizam-1 âlem kavramının bir tezahürüdür. Kamusal düzenin her şeyden daha ön planda tutuluyor olması şüphesiz şehzadelerin öldürülmelerini büyük toplumsal ve siyasal tepkilere meydan vermeyecek düzeyde sıradanlaştıran en önemli faktördür. Yine şehzadelerden birinin tahta geçerken hangi yaşta olursa olsun diğerlerinin hayatlarına son vermesi, kaderci ve teslimiyetçi bir inançla izah edilmiş ve acı da olsa sonuç büyük bir tevekkülle karşılanmıştır. Ya da böyle olması gerektiği düşünüldüğünden, içten duyulan duygusal reaksiyonlara rağmen dişarıya bu durum pek aksettirilmemiştir. Bu noktada Evliya Çelebi'nin kurguladığ1 ve "dünya oyunu (Evliya Çelebi, 1999:85)" olarak adlandırdığ1 şehzadeler arasındaki top müsabakasını anlattığı hikaye, Osmanlı devrindeki devlet, saltanat ve siyaset düşüncesi ve kaderci yaklaşımını çok güzel açıklamaktadır.

Evliya Çelebi, I. Ahmed'in şehzadeleri arasında yapılan bir top müsabakasını uzunca tasvir eder. Bu tiyatral anlatının başında Şehzade Osman'ın kardeşi Şehzade Mehmed'i top atarak yaralaması ve ona üstün gelmesi resmedilir. Oğullarını izleyen Sultan Ahmed, Mehmed'i kenara çekerek “Kayırmaz Mehemmedim! Seni 
uran li'ümm karındaşın Osman'dır. Dünya oyununun kâr böyledir. Sen dahi anı ur" diyerek oğlunu cesaretlendirir. Diğer taraftan Şehzade Murad kardeşleri Şehzade Bayezid ve Şehzade Süleyman'a üstün gelir. Yapılan mücadelede ikisinin de burnundan kan gelir. Sultan Ahmed, Murad'a neden böyle yaptığını sorduğunda cevap babasının cevabina benzer, ancak daha net ve vurucudur. "Vallahi Pâdişâhım, Murâdın murâdı eyle urmak değil idi. Ammâ dünya oyunudur, iktiza etdi. Zîrâ anlar geçende benim üst yanıma geçüp yerim almak istediler. Ben dahi şimdi firsat bulup urdum". Evliya bu hikaye ile şehzadeler arasında yaşanan rekabeti ve kavgayı bir dünya oyunu olarak tasvir etmiş ve bu düzenin böyle gelip böyle gittiğine dair inancın ne kadar yaygın olduğunu dile getirmiştir1 (Evliya Çelebi, 1999:85-87; Taştan, 2011:251), Hikayede dikkat çeken bir diğer husus da saltanatın güç ile bağdaştırılması ve mücadelede üstün gelenin her türlü hakka sahip olduğunun (buna kardeşi öldürmekte dahil) altının çizilmesidir.

Evliya Çelebi'nin ortaya koyduğu bu bakış açısı, Osmanlı kroniklerinde şehzadelerin öldürülmesiyle ilgili yaygın bir düşünceyi yansıtmaktadır. Bununla beraber şehzade katli vakıalarının tarih kitaplarında tuttuğu yer ve anlatılma üslubu, bazı gerçekliklerle alakalıdır. Bunlardan en önemlisi hiç şüphesiz şehzadeler arasında yaşanan taht mücadeleleridir. Fetret Dönemi'nde Yıldırım Bayezid'in oğulları arasında yaşanan savaşlar, Cem Sultan ve Bayezid arasında yaşanan mücadele, Şehzade Selim ve Şehzade Bayezid çekişmesi, Osmanlı tarihinde siyasi ve sosyal açıdan önemli

\footnotetext{
1 Evliya Çelebi b. Derviş Mehemmed Zılli, (1999), Evliya Çelebi Seyahatnamesi Topkapı Sarayı Băgdat 304 Yazmasının Transkripsiyonu-Dizini 2. Kitap, Haz: Zekeriya Kurşun, Seyit Ali Kahraman, Yücel Dağlı, İstanbul: Yapı Kredi Yayınları, s.85, 86, 87. Burada bahsi geçen hikayenin arka planı şu şekildedir. Girit'in fethine şahit olan Evliya Çelebi, dönüşte gelip babasının elini öpmüş̧ür. Babası Girit'in fethine I. Ahmed zamaninda karar verildiğini, I. Ahmed'in. Venediklilerden Girit'in Osmanlıya bırakılmasın talep ettiğini ancak ret cevabı aldığını belirtmiştir. Babasına göre duruma üzülen Sultan Ahmed, Hasbahçe'de oğullarının kendisini eğlendirmesini istemiştir. Bunun üzerine şehzadeler arasında bir top müsabakası gerçekleşmiştir. Bu husus daha önce bir çalışmada değerlendirilmiştir. Bk. Yahya Kemal Taştan, (2011), "Evliya Çelebi'nin Osmanlı Hanedanına Bakışı", Ed. Nuran Tezcan-Semih Tezcan, Doğumunun 400. Yılında Evliya Çelebi, Ankara: Kültür Turizm Bakanlığı Yayınları, s.251.
} 
sonuçlara yol açmış büyük hadiselerdir. Bu sebeple söz konusu şehzadeler Osmanlı tarihlerinde hem hayatları hem de taht mücadeleleri ve ölümleri ile geniş bir yer bulmuştur. Cem Sultan vakası bu açıdan önemli bir örnektir. Şehzade Cem'in Şehzade Bayezid ile giriştiği taht mücadelesi sonrasında isyan ederek Osmanlı topraklarını terk etmesi, esaret hayatı ve II. Bayezid veya Papa tarafından zehirletildiği iddiası tarihçilerin ilgisini çekmiş ve tarih kitaplarında geniş̧̧e anlatılmıştır. Cem Sultan vakası kronik yazarları kadar modern dönemde tarihçi ve edebiyatçılar arasında da popülerliğini korumuştur. Şehzade Cem'e olan ilgi muhakkak ki onun siyasi bir mücadeleye girmesi, emrindeki askerlerle birlikte Bursa' da hükümdarlığını ilan etmesi ve yol açtığı siyasi krizle doğrudan bağlantılıdır (Danişmend, 1954; Altınay, 2016, Vatin, 1997, Tağızade-Karaca, 2006).

İkinci önemli husus ise kaynaklardaki hem içerik hem de üslup sürekliliğidir. Önceki kaynaklarda aktarılan veriler sonrakileri de etkilemiş ve sonradan yazanlar ilk yazanların bilgisiyle metinlerini inşa etmişlerdir. Dolayısıyla bazı bilgi ve değerlendirmeler birbirinin tekrarı olmaktan öteye geçmemektedir. Örneğin, Yıldırım Bayezid'in babası ölür ölmez kardeşi Yakup Çelebi'yi çağırtıp babasının çadırında boğdurtması hadisesi kroniklerde yer alır. Vakıa politik yönüyle değerlendirilmiş olup şehzadenin ölümü kroniklerde "fitne öldürmekten daha zararlıdır (Hoca Sadettin Efendi, 1992:190)" düsturuyla ilişkilendirilmiştir. Bu düstur ileride nizam-1 âlem düşüncesiyle pekiştirilmiş ve ortaya devletin yaşaması için her yolun mubah olduğu bir anlayış çıkmıştır. Yani gereken ne ise o olmuş ve bitmiştir (Anonim Osmanlı Kroniği, 2000:34; Oruç Bey, 2009:34; İbn Kemal, 2000:5; Hadidi, 1991:106, 107; Aykun, 2004:4). Burada şehzadenin ölümünün savaş meydanının oluşturduğu gerilimli ortamda bir miktar geri plana düştügünü söylemek mümkündür. Keza tarihi yaşayan ile yazan arasındaki ilişki de anlatıları biçimlendirmiştir. Özellikle de ilk dönem Osmanlı kroniklerinin Ankara Savaşının kaybedilmesinden sonra kaleme alınmış olması ve dolayısıyla fetret döneminden yansıyan sıkıntılı sürecin tesiriyle yazıldıkları göz ardı edilmemelidir (Emecen, 2014:74). 
Üçüncüsü toplum nezdinde belirli bir konuma gelmiş, güç ve nüfuz sahibi olmuş şehzadelerin öldürülmesi birtakım sosyal ve siyasi olaylarla neticelenmiştir. Dolayısıyla bu gibi şehzadelerin hayat hikayeleri ile öldürülmeleri kroniklerde geniş yer bulmuştur. Kanuni'nin oğullarından Şehzade Mustafa ve Şehzade Bayezid'in ölümleri, bu hususa güzel bir örnektir. Kroniklerde Mustafa'nın ölümü dramatize edilerek aktarılmış ve toplumsal tepkiler etraflıca dile getirilmiştir. Mustafa'nın öldürülmesine yoğun bir tepkinin2 olması, şehzadenin toplum için değerli bir konumda bulunması ve halk tarafından geleceğin hükümdarı olarak görülmüş olmasıyla ilgilidir. Bu noktada şehzadenin bilgili ve liyakatli olması, etrafında çok sayıda devlet adamı, alim ve şairlerin bulunması da ona olan ilgiyi artırmıştır. Keza padişahın yaşının ilerlemiş ve şehzadelerin tahta oturmak için rekabete girmiş olması, şehzadeler arasında taraf tutan ve taht mücadelesine doğrudan müdahale eden devletlülerin de sayısını artırmıştır. Bu durum doğal olarak şehzade ölümlerini önce reel-politiğin sonra da siyasi tarihin bir parçası haline getirmiştir. Bu yüzden Şehzade Mustafa'nın öldürülmesi, kroniklerde, edebi eserlerde, seyahatnamelerde ve batılı opera ve tiyatrolarda (Kula, 2011a:56; Kula, 2011b:101)3 yer almış ve zihinlere adeta kazınmıştır.

Yukarıda sayılan hususlar, hem Osmanlı müelliflerinin hem de günümüz yazarlarının şehzade ölümlerine olan ilgisinin sebeplerini açıklamaktadır. Ancak her şehzade aynı ölçüde ilgi görmemiş, tarih kitaplarında bazılarına geniş yer ayrılırken bazıları ihmal edilmiştir. III. Mehmed'in tahta çıkışında öldürttüğü on dokuz

2 Özellikle Şehzade Mustafa için yazılan mersiyeler tepkinin boyutunu göstermesi açısından kıymetlidir. Mersiyeler için, Bkz. İsen, a.g.e, s. 283-323.

3 Şehzade Mustafa olayını yazıya döküp Avrupa kamuoyuna duyuran ilk kaynak Nikolaus Moffan'dır. İkinci kaynak Busbecq'tir ve üçüncü kaynak Lövenklav'dır. Bu eserlerde Kanuni'nin bir kadının hilesine kanıp oğlunu öldürtmesi, kişilik ve inanç zayıflığı olarak yansıtılmaktadır. Onur Bilge Kula, (2011), Batı Edebiyatında Oryantalizm I, İstanbul: Türkiye İş Bankası Kültür Yayınları, s. 56. Klasik batı müziğinde Solimano adını taşıyan operaların kaynağı Şehzade Mustafa vakıasıdır. Bu ismin verilme sebebi ise Kanuni'nin Avrupa'da kazandığı ündür. Onur Bilge Kula, (2011), Batı Edebiyatında Oryantalizm II, İstanbul: Türkiye İ̧ Bankası Kültür Yayınları, s. 101. 
kardeşinin hikayesi de bu ihmal dolayısıyla tarihin karanlığına ve bilinmezliğine terkedilmiş bir konu olarak kalmıştır.

\section{b. Osmanlı Tarihlerinde Katledilmiş “On Dokuz" Şehzade}

1595 'te Sultan Murad'ın vefatı üzerine 29 yaşında tahta oturan Sultan Mehmed (1595-1603) kendinden önceki padişahlar gibi kardeş katlini uygulamış ve on dokuz kardeşini öldürtmüştür. III. Mehmed'in cülusunda öldürülen şehzade sayısı Osmanlı tarihindeki en yüksek sayıdır. Keza daha kundaktaki çocukların öldürülmüş olması hasebiyle de en trajik hadisedir. Bu korkunç ve yürek parçalayan olaya, devrin kroniklerinde ve sonraki dönem Osmanlı tarihlerinde değinilmiş olmakla büyük oranda görmezden gelinmiştir. Tarih yazarları, Mustafa, Bayezid, Osman, Selim, Cihangir, Abdullah, Abdurrahman, Hasan, Ahmed, Yakup, Alemşah, Yusuf, Hüseyin, Korkut, Ali, İshak, Ömer, Alaüddin ve Davut (Çerçi, 1996:381) adlarındaki on dokuz şehzadenin ölümünü kısa birkaç cümle ile aktarmışlar, bu ölümlerin sosyal yansımaları ve Osmanlı duygu dünyasındaki etkileri hakkında tatmin edici düzeyde bilgi paylaşmamışlardır.

Devrin en önemli tarihçilerinden olan Selaniki Mustafa Efendi (ö. 1600) konuyla ilgili en ayrıntılı bilgi veren müelliftir. Şehzadelerin cenazelerinin babalarından bir gün sonra saraydan çıkarıldığını aktaran Selaniki, "On dokuz nefer şehzadeler içün serviden tabutlar ihzâr olunup ve cenâzelerine lâzım olan esbâb-ı mühimme hâzır u âmâde oldukta içerüde dilsiz ve dinsiz, feryâd u figânlarm işitmez üzerlerine musallat olup, maslahatlarm bitürüp" diyerek şehzadelerin öldürülmesinden hemen önce birtakım hazırlıkların yapıldı̆̆ını ve "dilsiz ve dinsiz" olarak isimlendirdiği cellatlarla şehzadelerin boğdurulduğunu aktarır. Selaniki'nin cellatlar için kullandığı ifadeler şehzadelerin ölümüne yönelik tepkisini ortaya koymaktadır. Ayrıca bu ifadelerle Selaniki, sorumluluğu cellatların üzerine yıkarak sistem ve saray eleştirisini hafifletmiş ve perdelenmiştir. Bununla beraber üzüntünün yoğun bir şekilde hissedildiği " $B a^{\prime} d e h \hat{u}$ ma'sûmlar musibetinün âh u nâleleri dûdı âsumâna çıkdı. Bu ateş ile yanmadık ciğer kalmadı. Dîdeler giryân ve diller büryân cenâzelerin getürüp babalarmın ayağı ucuna defn idüp intizâm virdiler" (Selaniki Mustafa Efendi, 1999:436) cümlelerinde ise şehzadelerin ma- 
sumiyetine ve kardeş katli uygulamasının acımasızlığına dikkat çekmiştir. Üzüntüyü dile getirdiği ifadelerinde açık bir şekilde insanların olaydan büyük teessür duyduğu ve hissettikleri elemden dolayı gökyüzüne dayanacak şekilde ağlayıp inlediklerini belirtmiştir.

Osmanlı topraklarına Avusturya elçilik heyetinde eczacı olarak gelen ve İstanbul'da zindana atılan Friedrich Seidel de eserinde bu hadiseye değinmiştir. Sultanın Zindanında adıyla Türkçeye çevrilen ve 1591-1596 yılları arasını kapsayan eserinde İstanbul halkının tepkileriyle ilgili dikkat çekici bilgiler vermiştir. Seidel, Selaniki'nin şehzade ölümlerinden dolayı oldukça üzüntülü olarak tasvir ettiği İstanbul halkının ertesi günkü durumunu "Padişah oğullarryla birlikte defnedildi ve bir gün sonra da Sultan Mehmed'in tahta geçişi kentin içinde bir alay düzenlenerek halka duyruldu. Bu olay da gene sevinç gösterileriyle, top atışlarıla ve havai fişeklerle kutlandı" ifadeleriyle resmeder (Seidel, 2010:61). Bu bilgiler, halkın şehzadelerin ölümüne üzüntü duymalarının hemen ertesi günü yeni padişahı tebrik için şenliklere katılması, acının geride bırakılıp, Osmanlı sultanına yüklenen kutsiyet dolayısıyla kutlamaların coşkuyla gerçekleştirildiğini göstermektedir.

Gelibolulu Mustafa Ali 1591-1599 yılları arasında kaleme aldığı eseri Künhü'l-Ahbar'da dönemi müşahede etmiş biri olarak bilgi vermektedir. Mustafa Ali'ye göre şehzadelerin öldürüldüğü gece sarayda büyük bir vaveyla kopmuştur. Anlatısında küçük yaştaki şehzadelerin validelerinin kucağından alınıp ölüme götürülüşünü aktarırken olayı trajik boyutuyla ele almıştır. Keza şair Nevî'nin şehzadeler ve III. Murad için yazdığı mersiyeden bahsetmiştir. Şehzadelere hocalık yapan ve sarayda büyük itibar gören Nevî, kendisinden büyük ihsanlar gördügü III. Murad'a yazdığı mersiye dışında şehzadelere de ayrıca mersiye kaleme almıştır. Eğitimlerinden sorumlu olduğu şehzadelerin öldürülmesi onu derinden yaralamış ve yaşadığı hüznü mersiye olarak dile getirmiştir. Mustafa Ali de Şair Nevî’nin ayrılık acısına dayanamayarak yazdığı mersiyeye atıf yaparak şehzadelerin ölümünün nasıl bir hüzne yol açtığına dikkat çekmiştir (Çerçi, 1996:674).

Şair Nevî, kaleme aldığı mersiyede öncelikle padişahın ölümün- 
den duyduğu üzüntüyü dile getirmektedir. Şehzadelere tek bir kişiymiş gibi mersiyesinde yer vermiş olması dikkate şayandır. "Şehzade- nâ-şâd-baht" mutsuz ve bahtsız şehzadeden kasit on dokuz şehzadedir. Şehzadelerin cenazesine çok fazla insanın geldiğini "Na'şinde âlem haşr olup bir özge divân oldı âh" misraryla dile getirir. Yaşanan durumu "Nev'î yiter kan agladun sûzân u nâlân inledün. Besdür şikâyet çarhdan Hakdan çü fermân oldı âh" beytiyle kadere bağlayan şair burada kendi üzüntüsünü de betimlemektedir. Mersiyede en dikkat çekici kısım ise yeni tahta çıkmış olan padişahla ilgili olan beyittir. "Bu saltanat gülzârnna Sultan Mehemmed Han yeter. Gül var iken bir goncasuz bagrum dime kan oldı âh". Saltanat bahçesinin gülü olarak tanımladığı III. Mehmed'in varlığının saltanatın yegane dayanağı olduğunu belirten şair, şehzadeyi/ şehzadeleri gonca olarak betimleyip Sultan Mehmed dolayısıyla açmış bir gül varken goncasız, yani "şehzadesiz kaldım” diye eseflenmenin yersiz olduğunu belirtir (İsen, 1994:326). Mersiyede bir şikayet veya eleştiriden ziyade üzüntünün dile getirilmesi esastır. Ayrıca bu beyitte, şehzadelerin kaybı büyük bir acı olmasına karşılık saltanatın devamının çok daha önemli olduğu vurgusu oldukça belirgindir. Bu mersiye şehzadelerin öldürülmüş olması karşısında duyulan acıyı yansıtsa da saltanatın devamını bir beka meselesi olarak görmesi sebebiyle şehzade ölümlerini değersizleştiren ve bir kenara atan yaygın tavra örnektir. Hatta açılmış bir gülün yanında henüz açmamış bir goncanın önemi olmadığını açıkça zikrederken pragmatik bir bakışı yansıtmaktadır. Keza bu tutum, şehzade ölümleri karşısındaki his körelmesinin nasıl bir düşünce ve zihniyet dünyasında oluştuğunu da açıklamaktadır.

Gelibolulu Mustafa Ali'nin III. Murad'a ithafen yazdığı satırlarda onun beş kardeşini öldürtmüş olmasını gündeme getirmesi de ilginçtir. Mustafa Ali, "beş şehzadeden bedel on tokuz nev-civan 'âlî... âşûb-ı siyâsete bogıldı" (Çerçi, 1996:674) ifadesi ile on dokuz şehzadesinin öldürülmesini, Sultan Murad'ın geçmişte beş kardeşini öldürtmesinin bir bedeli olarak gördüğünü gösterir. Mustafa Ali'ye göre masum beş kardeşinin canına kıymış olması karşılığında, kaderin bir cilvesi olarak kendisinin de on dokuz çocuğu öldürülmüş ve bir şekilde Sultan Murad cezalandırılmıştır. Sultan Murad 
öldüğüne göre Mustafa Ali'nin bu ifadeleri Osmanlı veraset sistemine yönelik ciddi bir tenkit ve III. Mehmed'e acı bir ihtardır. Sultan Murad beş kardeşini öldürterek ah aldığı için çocukları da aynı şekilde öldürülmüştür. Dolayısıyla ona göre, Sultan Mehmed on dokuz kardeşini öldürtmekle gelecekte benzer bir kadere mahkum olacaktır.

Peçevi, 16. yüzyıl sonlarını ve 17. yüzyıl başlarını görmüş bir tarihçi olmasına rağmen on dokuz şehzadeye ancak birkaç satır ayırmıştır. "O gece on dokuz şehzade, annelerinin kucağından kopartlarak Tanrı'nın rahmetine ulaştırıldılar. Ertesi gün Şeyhülislam Bostanzade onlarm cenaze namazların kıldırdı ve babaların ayakları dibine "hüzün köşesi" gibi gömüldüler. Yüce Tanrı'nın rahmeti üzerlerine olsun". Peçevi olayı dramatik bir şekilde resmetmiş ve şehzadelerin babalarının ayağının dibine adeta hüzün köşesi gibi gömüldüklerini ifade etmiştir (Peçevi, 1982:152). Duygusal bir yansımanın izlerini taşıyan Peçevi'nin ifadelerinde dikkat çeken esas husus, çocukların ana kucağından alındığına yapılan vurgudur. Birkaç satırlık bilgi olsa da Peçevi'nin bilinçaltını yansıtan bu ifadeler oldukça vurucudur.

1639'da vefat etmiş olan Bostanzade Yahya Efendi ise III. Mehmed'in sancaktan gelip tahta çıkmasını takiben kardeşlerine "şehadet şerbetini" içirdiğini ifade eder. Olayı kısa ve yalın bir şekilde ifade etmesinin hemen ardından Mehmed'in saltanatına atıfta bulunur ve onun padişah olmasıyla beraber yeryüzünü adalet ve doğruluğun kapladığını belirtir (Bostanzade Yahya, 2016:80). Bostanzade'nin bu yaklaşımı saltanat merkezli bir tarih anlatıs1nın uzantısıdır. Ancak şehzadelerin şehit olarak tanımlamış olması önemlidir. Birçok Osmanlı tarihçisinde görüldüğü üzere Yahya Efendi de şehzadeleri şehit saymıştır. Şehzadelerin şehit olarak zikredilmesi öldürülen çocukların masum olduklarına ve cennet çocukları olarak dirileceklerine olan bir vurgudur. Bu vurgu İslam inancındaki, Allah'ın şefkat sıfatının bir tecellisi olarak çocuk yaşta ölenlerin, eziyetli dünya hayatından kurtulduğu, Allah'ın inayeti ve rahmetine sığındığı, Cennetü'l-Firdevs'e gönderildiği, ahirette anne ve babasına sevgi ve şefkat vesilesi olacağı şeklindeki anlayışı hatıra getirmektedir. Bununla birlikte şehitlik makamına olan 
bu vurgu, kardeş katline yol açan Osmanlı siyaset anlayışını da meşrulaştıran ve masum gösteren bir işleve sahiptir. Şehit şehzadelerin ahiretteki durumlarını öne çıkaran bu yaklaşım, insanların acılarını hafiflettiği gibi şehzadelerin başına gelen ve musibet gibi görünen muamelenin de kabul edilmesini kolaylaştırmıştır. Keza onların ölümüne yol açan sistem de büyük tepkilerden kurtulmuş olmaktadır.

Aynı yaklaşım Osmanlı tarihçilerinin genelinde görülmektedir. Karaçelebizade Abdülaziz Efendi şehzadelerin ölümünü "on dokuz nefer şehzade mevcûd idi ki, bi-hükm-i hâkime-i mahkeme-i kadr ü kazâ vesikâ-i hayâtlarn kalem-i ecel-i mübrem ile mümzâ oldı (Özgül, 2010:167)" ifadesiyle doğrudan kaza ve kaderle ilişkilendirmektedir. Hayatlarının "ecel-i mübrem" kaçınılmaz ecel kalemiyle nihayete erdiğini söyleyerek olayı Allah'ın takdirine bağlar ve herhangi bir eleştiride bulunmaz. Bu yorum Abdülaziz Efendi'nin saltanat işlerini kanıksadığını yahut durumu kadere bağladığını göstermektedir. Abdülaziz Efendi de şehzadeleri şehit olarak göstermiştir.

17. yüzyıl tarihçilerinden Solakzade ise şehzadelerin öldürülmesine yönelik açık bir şekilde eleştiride bulunur. "Kıyameti andıran bir vakit" olarak adlandırdığı şehzadelerin öldürüldügü geceyi önce okuyucusunun zihninde canlandırır. "Kıyameti andıran o zamanda, Saray-ı hümâyûn içerisinde bulunan on dokuz aded şehzade, haksız yere hemen şehidler zümresine ilhâk olunmuşdur... Bu şehzadelerin tamamı o gün şehidler zümresine ilhâk olunmasına rağmen, ayn gün çıkarılmalarına mecâl bulunmadı. Akşam yakın olmakla zaman dar olduğu için, ertesi günü, sabah erkenden çıkarılarak namazları kılındı ve onlar da babaları, bir kızkardeşi de annelerinin yerine defn olundular". (Solakzade Mehmed Hemdemi Çelebi, 1989:362) Solakzade'nin şehzadelerin öldürülmesinden dolayı eleştirisi, haksız yere öldürüldükleri noktasına temas etmesiyle açığa çıkmaktadır.

Aynı yüzyılın büyük seyyahı Evliya Çelebi, on dokuz şehzadenin öldürülüşünü hikayeleştirerek ve sinematografik bir üslupla anlatmıştır: "Murad Han'ın ölümü sırasında hünkarlık yasası gereği on dokuz şehzadeyi bir seferde şehit ettiler. Hatta biri o kadar küçük imiş ki kestane yerken cellat öldürmeye gelince o şehzade "Katlan kestanemi 
yiyeyim sonra boğ" der. Actmasız cellat hemen şehit eder. Birini de şehit etmeye gelip annesi kucağından alır, bir bucakta boğazdan boğarken annesinin sütü burnundan, ruhu ă̆zından çııp ruhunu teslim eder" (Evliya Çelebi, 1996:147). Evliya bu acı hadiseyi "hünkarlık yasası gereği" ifadesi ile tarihsel bir bağlama oturtmakla birlikte olayın vahametini anlatmaktan çekinmemiştir. Bu tavır saray çevresinde ve halk arasındaki tepkinin en doğal halini ortaya koymaktadır. Şehit vurgusu diğerlerinde olduğu gibi Evliya'da da yer alır. Ac1masız cellat diyerek de suçu celladın üzerine yıkmıştır. Burada padişahtan bahsetmemiş olması dikkat çekmektedir. Suçu cellada yükleyerek masum şehzadelerin öldürülmesine yol açan sistemi ve asıl sorumluları perdelemiştir. Bununla birlikte padişahın adını zikretmemiş olması örtük bir şekilde sistem ve padişah eleştirisi olarak yorumlanabilir.

Bir diğer 17. yüzyıl tarihçisi Katip Çelebi on dokuz şehzadenin öldürülmesini sıradan bir vakıa gibi fazla detaya girmeden aktarır. "On dokuz şehzade bilâ-cürüm ve istihkak şühedi zümresine ilhak olundılar" ifadesi Katip Çelebi'nin şehzadelerin haksız ve günahsız yere öldürüldüğünün (şehit edildiğinin) altını çizmesi açısından mühimdir (Aycibin, 2007:266). Osmanlıların ilk vakanüvisi olan Naima Mustafa Efendi, kaleme aldığı eserinde on dokuz şehzadenin öldürülmesiyle ilgili kısma "ve ol zaman-ı kıyâmet-nişânda" diye başlayarak bahsetmektedir. Dolayısıyla O da Solakzade gibi şehzadelerin öldürüldüğü zamanı kıyamete benzetmiştir. Naima vakıayı şu ifadelerle anlatmıştır: "On dokuz nefer şehzade-i b̂̀-günah kemend-i cân-sitân ile şühedâ zümresine ilhâk ve pederleri merhuma hem-râh olup ertesi ale's-sabah cümlesinin Müfti Efendi namazın kılıp peder-i cennet mekânları ayağı ucunda defn olundular" (Naima Mustafa Efendi, 2007:19). Şehzadelerin günahsız yere bir kemendin ucunda can verdiğini ifade eden Naima' nın bu yaklaşımı, on dokuz şehzadenin öldürülmesi üzerine yaşanan ve hafızalarda yer tutmuş olan travmayı aksettirmektedir.

Geç dönem yerli ve yabancı tarihçiler de konuyla ilgili kısa da olsa bilgi vermişler ve değerlendirmelerde bulunmuşlardır. 19. yüzyıl tarihçilerinden Hayrullah Efendi ise on dokuz şehzadenin öldürülmesini farklı bir perspektiften değerlendirmektedir. Şehzade- 
lerin cenaze merasimlerinden bahseden Hayrullah Efendi "o gün öyle meşum bir gün idi ki" diyerek şehzadelerin öldürüldüğü günü lanetli bir gün olarak tanımlar. Haremdekilerin kucaklarından alınan velinimetlerinin cellatlar tarafından öldürülmesinin ardından feryat figan ederek acılarını dışa vurduklarına dikkat çeker. Ancak onun belki de bu olaydaki yanlışlığı vurgulamak için anlatısına eklediği konu, şehzade annelerinin haremden çıarılıp evlendirilmesidir. Hanedanın namusu olarak gördüğü harem cariyelerinin başka birileriyle evlendirilmesinin hanedanın namusuna halel getirdiğini düşünmektedir (Hayrullah Efendi, 1972:34, 35). Hayrullah Efendi'nin masum şehzadelerin öldürüldüğü kısımda annelerinin saraydan çıkarılıp evlendirilmesi bahsine değinmiş olması, Osmanlı saltanat düzeni ve harem sistemini kabul edilemez bulmasıyla yakından alakalıdır.

Yabancı yazarlardan Jorga ve Zinkeisen de meseleyi tarihi bir vakıa olarak aktarmışlar, meselenin ayrıntısına girmemişlerdir (Jorga, 2005:260; Zınkeisen, 2011:426). Ancak Hammer'ın III. Mehmed'in kardeş katli kanununa sadakat göstererek kardeşlerini öldürttüğünü belirtmesi, onun Osmanlı resmi bakışını yansıtmakta ve geçmişi yargılamak yerine anlamaya çalıştığı izlenimini vermektedir. Hammer'da on dokuz kardeşin öldürülmesi, kardeş katli kanunun bir gereği olduğu vurgusu açık bir şekilde hissedilir. Öyle ki bu elim hadisenin yarattığı hüzne yer verdiği "Me'yûsâne mukavemetlerinin, katilleri hakkındaki tel'înlerinin derin bir meçhuliyyet içinde kalması için şehzadelerin idamı dilsizlere havale edildi" ifadelerinde bile devletin veya düzenin bakış açısını öne çıkarmıştır. Hammer'ın şehzadelerin ölümden kurtulmak için çaresizce direnişlerinin ve cellatlarına okudukları lanetlerin meçhulde kalması ve bilinip duyulmaması için idamların dilsizlere yaptırıldığına dikkat çektiği bu ifadeler devletin iradesini yansıtmaktadır. Bu tespit, on dokuz şehzadenin katli hadisesinin tarih kitaplarında yeterince yer almaması, şiirlere ve hikayelere konu olmamasının asıl sebebine işaret eder (Hammer, 1993:227).

Yukarıda III. Mehmed'in cülusu sebebiyle on dokuz şehzadenin öldürülme hadisesinin Osmanlı tarihlerinde nasıl yer aldığı, hangi bağlamda konuya değinildiği ve nasıl bir üslupla yazıldığı 
üzerinde duruldu. Ancak yapılan okuma ve değerlendirmelerde Osmanlı tarihinin en trajik olaylarından biri olmasına rağmen on dokuz şehzadenin öldürülmesinin tarihi metinlerde yeterince yer bulmadığı ve olayın etraflıca değerlendirilmediği görülmüştür. Bu durumda Cem Sultan, Şehzade Bayezid ve Şehzade Mustafa gibi şehzadelerin ölümüyle karşılaştırıldığında niçin bu on dokuz kardeşin ölümü yeterince ilgi çekmemiş ve tarih kitaplarında yer bulmamış sorusu akla gelmektedir. Bunun birkaç önemli sebebi olduğunu düşünüyorum. Osmanlı tarih yazımında ve Osmanlı tarihlerinde şehzade katli başlı̆̆ında belirttiğim üzere şehzade ölümlerinin büyük birer tarihi hadise olabilmesi bazı siyasi ve sosyal faktörlerle yakından alakalıdır. Bunlardan en mühimi şehzadenin doğrudan taht mücadelesine girip girmediği ve isyan edip etmediği meselesidir. Mesela Şehzade Cem veya Şehzade Mustafa isyan ettikleri ve taht mücadelesine girdikleri için doğal olarak tarihin de önemli bir parçası olarak kabul edilmişlerdir. $\mathrm{Bu}$ isyanlar Osmanlı Devleti'ni hem içeride hem dışarıda birçok krizle karşı karşıya getirdiği için isyan etmiş şehzadeler birer hanedan mensubu olmaktan çok siyasi ve sosyal sürecin bir parçası olarak tarihçinin de gündeminde olmuştur. Halbuki on dokuz şehzade, herhangi bir taht mücadelesine girmedikleri gibi rekabet ortamını oluşturacak imkanlara da sahip değillerdi. Dolayısıyla onların öldürülmelerine olan ilgi şehzadelerin çocuklukları ve masumiyetleri ile sınırlı kalmıştır. Bu da doğal olarak on dokuz şehzadenin tarih kitaplarındaki yerini sınırlandırmıştır.

Şehzade ölümlerinin tarih kitaplarına geçmesini etkileyen ikinci faktör şehzadenin gücü ve çevresiyle ilgilidir. Şehzadelerin sancakbeyliği görevinde bulunmaları, idari ve askeri görevleri dolay1sıyla kendine sadakatle bağlı yakın bir çevre oluşturabilmeleri ve toplum nezdinde belli bir itibara sahip olmaları kendilerini tarihsel bir aktöre dönüştürmekteydi. Böyle bir şehzadenin isyanının da öldürülmesinin de büyük gürültülere yol açması doğaldı. Şehzade Mustafa'yı örnek verecek olursak, Mustafa, sancağı bulunan, güçlü, nüfuz sahibi, devlet adamları, asker ve halk tarafından sevilen, babasının yaşı ilerlemiş olması sebebiyle tahta aday görülen bir şehzadeydi. Bu sebeple Şehzade Mustafa'nın etrafında onun 
padişahlığını isteyen, ona bel bağlamış, ikbal arzuları ile onun safında yer tutmuş veya ona inanmış ve muhabbet duyan geniş bir kitle oluşmuştu. Dolayısıyla onun öldürülmesi yalnızca bir şehzadenin öldürülmesi olarak geçiştirilemezdi. Çünkü Mustafa'nın öldürülmesi, ona sevgiyle veya çıkar beklentisiyle bel bağlamış ümera, ulema ve askerlerin de hayallerinin yıkılması demekti. Bu sebeple Şehzade Mustafa'nın etrafında toplanmış kişi veya topluluklar, onun öldürülmesini daha fazla dramatize etmişler, onun hakkı için isyana kalkışmışlar ve hakkında çeşitli şiirler ve hikayeler yazmışlardır. Buna karşılık III. Mehmed'in öldürttüğü on dokuz şehzadenin yaşları küçüktü, saray dışına çıkmamışlardı ve hiçbir şekilde siyasi bir aktör haline dönüşmemişlerdi. Dolayısıyla onların ölümünü dava konusu yapacak bir çevreleri de yoktu. Onların ölümü yalnızca küçük yaştaki masumların öldürülmesi gerçeği ile sınırlıydı.

Üçüncüsü ise şehzadelerin katledilmesinin, Şehzade Bayezid ve Şehzade Mustafa örneklerinde olduğu gibi siyasal ve sosyal kırılmalara yol açmış olmasıdır. Buna karşılık III. Mehmed döneminde yaşanan bu olay siyasal açıdan dönemini etkileyecek herhangi bir değer taşımamaktadır. Her ne kadar I. Ahmed döneminde kardeş katli uygulamasından vaz geçilerek "ekber ve erşed" sisteminin uygulanmaya başlanmasında on dokuz kardeşinin öldürülmesinin yarattığı elemin bir etkisi olsa da esas sebep başkadır. I. Ahmed tahta oturduğunda daha 14 yaşındayd 1 ve kendisinin yerine varis olacak bir çocuğu da yoktu. Hanedanın beka meselesi, yüzyıllardan beri uygulanan kardeş katli uygulamasının da sonunu hazırlamıştı.

Şehzadelerin öldürülmesinin tarih kitaplarına yansımasını etkileyen dördüncü faktör Osmanlı resmi ideolojisinin ortaya koyduğu tutumdur. Hammer'ın ortaya koyduğu gibi Osmanlılardaki düzen ve saltanat anlayışı gereğince, böylesine acı bir hadisenin dillendirilmesi, kulaktan kulağa aktarılması ve toplumda teessüre yol açacak trajik bir hikayenin oluşması hoş karşılanmazdı. Bu yüzden Osmanlı tarihçileri de on dokuz şehzadenin öldürülmesini, devlet merkezli bir perspektifle kaleme aldılar. Eserlerinde yaşanan acıya yer verirken, anlattıklarını çoğunlukla kader inancı ve şehitlik makamı ile sınırlı tuttular. 
Son olarak çok sayıda küçük ve masum şehzadenin öldürülmesi, büyük bir tarihi hadise olma potansiyeline sahip iken sayının çokluğu ironik bir şekilde öldürülenlerin önemsizleştirilmesine yol açtı. Çoğunlukla on dokuz şehzadenin isimleri anılmadı, kim oldukları önemsenmedi veya isimlerinin zikredilmesine gerek bile duyulmadı. Hatta şehzadelerin çokluğu, "on dokuz şehzade" ibaresi, bu elim vakanın tarihçiler tarafından soğukkanlı bir şekilde kaleme alınmasını kolaylaştırdı.

\section{Sonuç}

Yapılan araştırmada III. Mehmed'in cülusunda on dokuz kardeşini öldürtme hadisesinin kısa da olsa bir şekilde Osmanlı tarihlerinde yer aldığı görülmüştür. Ancak diğer şehzadelerin ölümleri ile karşılaştırıldığında on dokuz kardeşin ölümüyle ilgili tarihsel bilgilerin sinırlı olduğu ve tarih kitaplarına yeterince geçmediği tespit edilmiştir. Bununla birlikte bu vakaya kısa da olsa yer veren Osmanlı müellifleri, hadisenin trajik boyutuna dikkat çekmişler, yaşananlar karşısında duyulan hüzün ve acıyı bir şekilde yansıtmışlardır. Ancak tarihçilerin hemen hepsi meseleyi Osmanlı resmi perspektifi ile okuyucularına aktarmışlardır. Onlara göre şehzadelerin öldürülmesi, siyaset oyununun bir parçası ve saltanat düzeninin doğal bir sonucudur. Keza tarihçilerin üslubunda kaderci bir tutum söz konusudur. Yine ölen çocukların şehit oldukları ve doğrudan cennete gittikleri inancıyla, yaşanan acı hafifletilmeye ve olay karşısında gösterilecek isyankar tavırların da anlamsız olduğu vurgulanmaya çalışılmıştır. 1595 'te gerçekleşmiş olan bu elim hadisenin tarih kitaplarında yer almasıly ilgili belirtilmesi gereken diğer bir husus da olayın üzerinden zaman geçtikçe müelliflerin daha eleştirel bir bakışa sahip olduklarıdır. 


\section{Kaynakça}

AKMAN, Mehmet, (1997), Osmanlı Devletinde Kardeş Katli, İstanbul: Eren Yayıncilık.

ALTINAY, Ahmet Refik, (2016), Sultan Cem, 2. Basım, İstanbul: Tarih Vakfı Yurt Yayınları.

ANONIM OSMANLI KRONİĞ (1299-1512), (2000), Haz: Necdet Öztürk, İstanbul: Türk Dünyası Araştırmaları Vakfı.

AYCİBIN, Zeynep, (2007), Katip Çelebi Fezleke Tahlil ve Metin I, Doktora Tezi, Mimar Sinan Güzel Sanatlar Üniversitesi, İstanbul.

AYKUN, Muhittin, (2004), Abdurrahman Hibri Efendi Defter-i Ahbar (Transkripsiyon ve Değerlendirme), Yüksek Lisans Tezi, Marmara Üniversitesi, İstanbul.

BOSTANZADE YAHYA, (2016), Duru Tarih, Haz: Necdet Sakaoğlu, İstanbul: Alfa Yayınları.

ÇERÇİ, Faris, (1996), Künhü'l-Ahbara'a Göre II. Selim, III.Murad, III. Mehmed Devirleri ve Ali'nin Tarihçiliği, Doktora Tezi, Erciyes Üniversitesi, Kayseri.

DANIŞMEND, İsmail Hami, (1954), “Gurbetname-i Sultan Cem”, Fatih ve İstanbul, c.II, (7/12), s.211-270.

EKİNCİ, Ekrem Buğra, (2006), “Osmanlı Hukukunda Kardeş Katli Meselesi", Prof. Dr. Fikret Eren'e Armağan, (s.1105-1117), Ankara: Yetkin Yayınları.

ELÇİN, Şükrü, (1974), “Kul Piri ve Şehzade Bayezid Ağıtı”, Türk Kültürü̈ Dergisi, (146), s.78-80. -, (1990), Türkiye Türkçesinde A ̆̆ıtlar, Ankara: Kültür Bakanlığı Yayınları.

EMECEN, Feridun, (2014), “İhtirasın Gölgesinde Bir Sultan: Yıld1rım Bayezid", Osmanlı Araştırmaları, (43), s.67-92.

ERSOYLU, İ. Halil, (2013), Cem Sultan'ın Türkçe Divan'ı, 2. Baskı, Ankara: Türk Dil Kurumu Yayınları.

EVLIYYA ÇELEBİ B. DERVIŞ MEHEMMED ZILLİ, (1999), Evliya Çelebi Seyahatnamesi Topkap Sarayı Bağdat 304 Yazmasının Transkripsiyonu-Dizini 2. Kitap, Haz: Zekeriya Kurşun, Seyit Ali Kahraman, Yücel Dağlı, İstanbul: Yapı Kredi Yayınları. 


\section{(1996), Evliya Çelebi Seyahatnamesi Topkapr} Sarayı Bağdat 304 Yazmasının Transkripsiyonu-Dizini 1. Kitap, Haz: Orhan Şaik Gökyay, İstanbul: Yapı Kredi Yayınları.

HADİİ, (1991), Tevarih-i Al-i Osman 1299-1523, Haz: Necdet Öztürk, İstanbul: Edebiyat Fakültesi Basımevi.

HAYRULLAH EFENDİ, (1972), Osmanl Devleti Tarihi VII, Haz: Zuhuri Danışman-Mesude Hunsari, İstanbul: Son Havadis Yayınları.

HOCA SADETTIN EFENDİ, (1992), Tacü't-Tevarih I, 3. Baskı, Haz: İsmet Parmaksızoğlu, Ankara: Kültür Bakanlığı Yayınları.

İBN KEMAL, (2000), Tevarih-i Al-i Osman, IV. Defter, Haz: Koji İmazawa, Ankara: Türk Tarih Kurumu Yayınları.

İSEN, Mustafa, (1994), Acıyı Bal Eylemek-Türk Edebiyatında Mersiye, 2. Baskı, Ankara: Akçağ Yayınları.

JORGA, Nicolae, (2005), Osmanl Imparatorluğu Tarihi III (15381640), Çev: Kemal Beydilli, İstanbul: Yeditepe Yayınları.

KULA, Onur Bilge, (2011), Batı Edebiyatında Oryantalizm I, İstanbul: Türkiye İş Bankası Kültür Yayınları,

(2011), Batı Edebiyatında Oryantalizm II, İstanbul: Türkiye İş Bankası Kültür Yayınları.

MUMCU, Ahmet, (1963), Osmanlı Devletinde Siyaseten Katl, Ankara: Ajans Türk Matbaası.

NAİMA MUSTAFA EFENDİ, (2007), Tarih-i Naima I, Haz: Mehmet İpşirli, Ankara: Türk Tarih Kurumu Yayınları.

ORUÇ BEY, (2009), Osmanlı Tarihi (1288-1502): Uç Beyliğinden Dünya Devletine, Haz: Necdet Öztürk, İstanbul: Çamlıca Basım Yayin.

ÖZCAN, Abdülkadir, (1981), “Fatih'in Teşkilat Kanunnamesi ve Nizam-1 Alem İçin Kardeş Katli Meselesi", İstanbul Üniversitesi Edebiyat Fakültesi Tarih Dergisi, (33), s.7-56.

ÖZGÜL, İbrahim, (2010), Kara Çelebi-Zâde Abdülaziz Efendi'nin Ravzatü'l-Ebrâr Adlı Eseri (1299-1648) Tahlil ve Metin, Doktora Tezi, Atatürk Üniversitesi, Erzurum.

PEÇEVİ İBRAHIM EFENDİ, (1982), Peçevi Tarihi II, Haz: Bekir Sit- 
kı Baykal, Ankara: Kültür ve Turizm Bakanlığı Yayınları.

SEIDEL, Friedrich, (2010), Sultanın Zindanında-Osmanl Imparatorluğu'na Gönderilen Bir Elçilik Heyetinin İbret Verici Öyküsü (1591-1596), Çev: Türkis Noyan, İstanbul: Kitap Yayınevi.

SELÂNİKî MUSTAFA EFENDİ, (1999), Tarih-i Selânikî II (10031008/1595-1600), 2. Baskı, Haz: Mehmet İpşirli, Ankara: Türk Tarih Kurumu Yayınları.

SOLAKZADE MEHMED HEMDEMİ ÇELEBİ, (1989), Solakzade Tarihi II, Haz: Vahid Çabuk, Ankara: Kültür Bakanlığ1 Yayınları.

TAĞIZADE-KARACA, Nesrin, (2006), “Batılı Üç Eserde 'Romantik Kurban' Cem Sultan”, BILİG, (39), s.167-184.

TAŞTAN, Yahya Kemal, (2011), “Evliya Çelebi'nin Osmanlı Hanedanına Bakışı”, Ed. Nuran Tezcan-Semih Tezcan, Doğumunun 400. Yılında Evliya Çelebi, (s.240-260), Ankara: Kültür Turizm Bakanlığı Yayınları.

TUNÇ, Muhammet Nuri, (2014), “Osmanlı'da Hanedan İçi Katl”, Turkish Studies, International Periodical fort he Languages, Literature and History of Turkish or Turkic, (9/4), s.1133-1167.

VATIN, Nicolas, (1997), Sultan Djem, Ankara: Türk Tarih Kurumu Yayınları.

VON HAMMER PURGSTALL Baron Joseph, (1993), Büyük Osmanlı Tarihi IV, Haz: Mümin Çelik-Erol Kılıç, İstanbul: Üçdal Neşriyat.

ZINKEISSEN, Johann Wilhelm, (2011), Osmanlı Imparatorluğu Tarihi III, Çev: Nilüfer Epçeli, İstanbul: Yeditepe Yayınları. 